\title{
PENGEMBANGAN BUKU SAKU DIGITAL BERBASIS ANDROID PADA MATA PELAJARAN PEMROGRAMAN DASAR DI KELAS X SMK YAPALIS KRIAN
}

\author{
Miftahul Jannah ${ }^{1}$, Fitria Nur Hasanah ${ }^{2}$ \\ Pendidikan Teknologi Informasi, Fakultas Psikologi dan Ilmu Pendidikan Universitas Muhammadiyah Sidoarjo \\ Jl. Majapahit 666B Sidoarjo \\ E-mail: jannahmiftahul858@gmail.com ${ }^{1}$, fitrianh@umsida.ac.id ${ }^{2}$
}

\begin{abstract}
ABSTRAKS
Tujuan penelitian ini untuk menghasilkan produk bahan ajar berupa buku saku digital berbasis android pada mata pemrograman dasar kelas X SMK. Model pengembangan yang digunakan yaitu model ADDIE yang terdiri atas tahap analysis (analisis), design (desain), development (pengembangan), implementation (implementasi) dan evaluation (evaluasi). Tahap analysis merupakan analisis kebutuhan yang digunakan untuk penyusunan buku saku digital; tahap design merupakan tahap pembuatan rancangan awal buku saku dgital berupa storyboard kemudian didesain menggunakan aplikasi desain dan juga pembuatan konten yang akan digunakan pada tahap selajutnya; tahap development merupakan tahap dimana desain dan konten yang telah dibuat masukkan ke dalam Adobe Animate CC 2017, setelah buku saku digital jadi maka tahap selanjutnya yaitu validasi buku saku digital, revisi tahap 1, uji coba perorangan, revisi tahap 2 dan uji coba kelompok kecil; tahap implementation merupakan tahap penerapan buku saku digital; tahap evaluation merupakan tahap memberikan penilaian terhadap buku saku digital dan juga melihat keefektifannya. Namun tahap implementation dan evaluation tidak dilakukan karena keterbatasan situasi dan kondisi karena adanya pandemi Covid'19. Berdasarkan hasil pengembangan didapatkan hasil bahwa pengembangan buku saku digital berbasis adroid pada mata pelajaran pemrograman dasar di kelas X SMK Yapalis Krian dinyatakan layak sebagai bahan ajar. Hasil validasi ahli media mendapatkan nilai sebesar $85 \%$ dengan kategori sangat layak, hasil validasi ahli materi mendapatkan nilai sebesar 92\% dengan kategori sangat layak dan respon siswa mendapatkan nilai sebesar 83,98\% dengan kategori sangat layak.
\end{abstract}

Kata Kunci: Bahan Ajar, Buku Saku Digital, Android, Pemrograman Dasar, SMK

\begin{abstract}
The purpose of this research is to produce teaching material products in the form of an Android-based digital pocket book in the basic programming eyes of class X SMK. The development model used is the ADDIE model which consists of the stages of analysis (analysis), design (design), development (development), implementation (implementation) and evaluation (evaluation). The analysis stage is a needs analysis used for the preparation of a digital pocket book; the design stage is the stage of making the initial design of a digital pocket book in the form of a storyboard then designed using a design application and also creating content that will be used in the next stage; the development stage is the stage where the design and content that has been created are entered into Adobe Animate CC 2017, after the digital pocket book is finished, the next stage is digital pocket book validation, stage 1 revision, individual trial, stage 2 revision and small group trial; the implementation stage is the stage of implementing the digital pocket book; the evaluation stage is the stage of providing an assessment of the digital pocket book and also seeing its effectiveness. However, the implementation and evaluation stages were not carried out due to limited situations and conditions due to the Covid'19 pandemic. Based on the results of the development, it was found that the development of an Android-based digital pocket book on basic programming subjects in class X SMK Yapalis Krian was declared feasible as teaching material. The results of media expert validation get a score of $85 \%$ with a very decent category, the results of material expert validation get a value of $92 \%$ with a very decent category and student responses get a score of $83.98 \%$ with a very decent category.
\end{abstract}

Keywords: Teaching Materials, Digital Pocket Book, Android, Basic Programming, SMK

\section{PENDAHULUAN}

\subsection{Latar Belakang}

Salah satu lembaga pendidikan yang mengembangkan kinerja untuk siap terjun dalam dunia kerja serta menciptakan sumber daya manusia agar memiliki keterampilan, kemampuan, dan keahlian yaitu Sekolah Menengah Kejuruan atau biasa disebut SMK (Edi et al., 2017). Salah satu program keahlian di SMK yang berkaitan dengan penggunaan berbagai media yang menjadi salah satu program keahlian favorit yaitu Multimedia. Pada progam keahlian Multimedia siswa diajarkan 
berbagai keahlian tentang bagaimana mendesain, instalasi komputer, produksi film dan sinema, sistem komputer dan pemrograman. salah satu dari mata pelajaran yang kurang diminati siswa yaitu pemrograman dasar, hal ini karena siswa sulit memahami bahasa pemrograman. Menurut Faiqoh (2015) berpendapat bahwa siswa kesulitan memahami mata pelajaran pemrograman dasar dikarenakan tidak dapat memvisualisasikan materi yang disampaikan.

Pemrograman dasar yaitu salah satu mata pelajaran yang mempelajari dasar logika dimana terdapat sintak-sintak atau instruksi yang bersifat universal (Kemdikbud, 2014). Proses pembelajaran disekolah biasanya dilakukan di laboratorium komputer dan didampingi oleh guru, namun beberapa bulan terakhir poses belajar mengajar mengalami kendala, hal tersebut terjadi karena adanya pandemi Covid'19. Dengan adanya pandemi Covid'19 tersebut jam belajar siswa disekolah berkurang dan menghindari kerumunan saat dikelas sehingga siswa tidak dapat melakukan praktikum di laboratorium komputer.

Covid'19 memberikan dampak yang besar khususnya dalam dunia pendidikan yaitu penurunan capaian belajar siswa, keterbatasan penggunaan kuota dalam belajar dan minat belajar siswa menurun. Menurut kebijakan Menteri Pendidikan dan Kebudayaan dalam surat edaran nomor 15 tahun 2020 tentang penyelenggaraan belajar dari rumah bahwa proses pembelajaran saat pandemi Covid'19 dilakukan secara daring. Dengan proses pembelajaran secara daring, sebagian besar siswa mengalami kesulitan dalam belajar karena tidak ada pendampingan secara langsung dari guru.

Berdasarkan hasil observasi yang dilakukan di SMK Yapalis Krian pada bulan November 2020 diperoleh informasi bahwa proses pembelajaran dilakukan secara daring. Dari hasil observasi tersebut terlihat bahwa kurangnya antusias siswa dalam belajar sehingga hasil belajar siswa mengalami penurunan, hal ini ditunjukkan dengan nilai ujian harian siswa dibawah rata - rata sehingga diperlukan bahan ajar berupa buku saku digital sebagai penunjang pembelajaran. Hal tersebut didukung oleh penelitian dari (Suryaningsih, 2020) yang berpendapat bahwa dalam situasi pandemi Covid'19 motivasi belajar siswa menurun sehingga berdampak pada hasil belajar siswa. Dengan dampak tersebut, guru harus mampu mengemas suatu pembelajaran yang efektif (Mastura \& Santaria, 2020).

Salah satu faktor penunjang pembelajaran yang efektif agar tercapainya tujuan pembelajaran yaitu menggunakan bahan ajar. Bahan ajar yaitu alat pembelajaran yang didalamnya terdapat materi pembelajaran untuk mencapai kompetensi yang diharapkan (Kusumam et al., 2016). Penggunaan smartphone dalam dunia pendidikan saat ini perlu digunakan sebagai alat penunjang dalam proses pembelajaran. Salah satu penggunaan smartphone dalam proses pembelajaran yaitu penggunaan buku saku digital.

Buku saku digital dapat digunakan sebagai alternatif proses pembelajaran dikarenakan buku saku digital mampu memberikan daya tarik siswa untuk belajar dan siswa dapat belajar dimanapun dan kapanpun mereka berada. Buku saku digital juga dapat meningkatkan minat belajar siswa (Widodo \& Wijatmo, 2017). Berdasarkan temuan diatas, maka dilakukan penelitian dan pengembangan yang berjudul "Pengembangan Buku Saku Digital Berbasis Android Pada Mata Pelajaran Pemrograman Dasar di Kelas X SMK Yapalis Krian.”

\subsection{Kajian Pustaka}

a. Sekolah Menengah Kejuruan

Sekolah Menengah Kejuruan (SMK) yaitu lembaga pendidikan yang menciptakan sumber daya manusia agar memiliki kemampuan keahlian dan keterampilan sehingga lulusannya dapat mengembangkan kinerja untuk siap terjun ke dunia kerja. SMK mempunyai tujuan yaitu mempersiapkan peserta didik untuk masuk ke dunia kerja, mengembangkan kompetensi dan pemilihan karier siswa (Billett, 2011). SMK dituntut harus mampu menciptakan siswa untuk beradaptasi dengan ilmu pengetahuan dan juga teknologi. Sebagai pencetak tenaga kerja, siswa SMK dibekali dengan keterampilan dan pengetahuan yang sesuai dengan kompetensi program kejuruan masing-masing siswa. Mata pelajaran kejuruan yaitu mata pelajaran yang mengarah pada pengembangan kemampuan dan penguasaan kejuruan yang dipersiapkan untuk siap ke dunia kerja. Teori menjadi sumber pengetahuan siswa agar mengerti mengenai praktik, apabila terjadi kesalahan dalam pemahaman teori maka akan menyebabkan kesalahan dalam praktiknya nanti. Kegiatan praktik yaitu langkah atau bukti nyata dari apa yang dipahami pada teori.

Lulusan SMK berperan untuk memenuhi dunia kerja yaitu dengan dibekali kemampuan pengetahuan (kognitif) dan kemampuan keterampilan (psikomotorik). Selain menguasai kompetensi di bidangnya, siswa harus mampu mengembangkan potensi diri agar siap berkompetisi pada saat ini atau di masa mendatang. Salah satu program keahlian di SMK yang berkaitan dengan penggunaan berbagai media yang menjadi salah satu program keahlian favorit yaitu Multimedia dikarenakan memiliki prospek kerja yang cukup bagus dan memiliki banyak keahlian yaitu designer, programmer, editor dan lain-lain (Renesia, 2020).

Pada progam keahlian Multimedia siswa diajarkan berbagai keahlian tentang cara mendesain, instalasi komputer, produksi film dan sinema, teknik animasi 2D dan 3D, teknik pengolahan audio dan video, sistem komputer dan pemrograman. Prospek kerjanya pun cukup luas misalnya designer, 
programmer, software development, game development dan sebagainya membuat program keahlian multimedia cukup diminati oleh peserta didik.

\section{b. Bahan Ajar}

Bahan ajar yaitu alat pembelajaran yang didalamnya terdapat materi pembelajaran untuk mencapai kompetensi yang diharapkan (Kusumam et al., 2016). Bahan ajar dapat memberikan pengalaman belajar bagi siswa serta meningkatkan proses pembelajaran menjadi efektif dan efisien. Kompetensi pembelajaran tercapai yaitu dengan adanya bahan ajar yang dikemas sesuai dengan kebutuhan kurikulum. Guru harus mampu merancang bahan ajar untuk keberhasilan proses belajar. Pembelajaran yang efektif, menarik dan efisien membutuhkan bahan ajar yang kreatif, inovatif, variatif dan sesuai dengan kebutuhan siswa.

Fungsi bahan ajar menurut Hernawan (2017) dalam M. Djauhar Siddiq yaitu (a)Sebagai pemandu guru, membimbing kegiatan dalam proses pembelajaran dan dijadikan sebagai konten keterampilan yang akan diajarkan kepada siswa; (b)Sebagai pedoman bagi siswa untuk melakukan kegiatan dalam proses pembelajaran dan sebagai substansi kompetensi yang harus dikuasai siswa; (c)Alat evaluasi pencapaian/penguasaan hasil pembelajaran.

Prinsip memilih bahan ajar menurut Pratowo dalam (Aprelliyanto, 2019) yaitu (a)Prinsip relevansi atau keterkaitan yaitu bahan ajar hendaknya relevan atau adanya hubungan dengan pencapaian SK dan KD; (b)Prinsip konsistensi atau keajegan yaitu kompetensi dasar yang dikuasi siswa dengan bahan ajar harus memiliki keselarasan; (c)Prinsip kecukupan yaitu bahan ajar yang diajarkan cukup memadai dalam membantu siswa untuk menguasai kompetensi yang diajarkan.

Bahan ajar berdasarkan bentuknya dibedakan menjadi empat macam (Agustina, 2018) yaitu (a)Bahan ajar cetak yaitu bahan ajar dalam kertas (printed), misalnya buku teks, modul, handout, lembar kerja siswa dan brosur; (b)Bahan ajar dengar yaitu berbentuk audio dengan menggunakan sinyal radio, misalnya kaset, piring hitam atau compact disk audio; (c)Bahan ajar pandang yaitu bahan ajar kombinasi antara sinyal audio dengan gambar bergerak, misalnya film dan video compact disk; (d)Bahan ajar interaktif yaitu bahan ajar dengan dua kombinasi dari dua media atau lebih (audio, video, teks, animasi dan gambar), misalnya compact disk interactive.

\section{c. Buku}

Buku yaitu salah satu bahan ajar yang digunakan oleh guru dan sebagai sumber belajar bagi siswa. Dalam proses pembelajaran, buku menjadi sumber belajar bagi siswa yang paling utama (Anisah \& Azizah, 2016). Buku berisi tulisan dan gambar yang ditulis dilembaran, papirus, perkamen, lontar dan kertas berupa gulungan, dilubangi atau dijilid muka dan belakangnya dengan karton ataupun kulit (Rahmawati, 2016). Didalam buku mencakup kompetensi dasar yang sesuai dengan kurikulum dalam satuan lembaga pendidikan.

Buku menjadi pegangan siswa dalam belajar serta sebagai pendukung kegiatan belajar. Buku berisi mengenai materi yang disusun sistematis serta terdapat soal-soal yang dapat dikerjakan oleh siswa untuk melatih pemahaman siswa. Buku juga membantu guru untuk menyampaikan materi yang akan diajarkan sehingga tujuan pembelajaran dapat tercapai. Buku teks yang ada disekolah yaitu dapat berupa buku paket, modul, handout, dan lembar kerja. Dengan adanya buku, kegiatan belajar mengajar dapat berjalan sesuai dengan tujuan pembelajaran.

\section{d. Buku Saku Digital Berbasis Android}

Buku saku merupakan buku yang mudah disimpan didalam saku dan dapat dibawa kemanamana (Nasional, 2008). Selain itu (Putri, 2017) berpendapat buku saku merupakan buku yang berukuran kecil dan ringan yang dapat dibaca kapanpun dan mudah dibawa kemana-mana. Defisini umum buku saku yaitu buku yang ukurannya kecil didalamnya berisi suatu informasi dan dapat disimpan didalam saku sehingga dapat dibaca kapanpun dan dimanapun.

Buku saku digital yaitu pengembangan dari mobile learning salah satunya yaitu buku saku digital yang mudah digunakan dalam pengoperasiannya (Hanif, 2018). Didalam buku saku digital ini menerapkan prinsip desain pembelajaran yang efisien, efektif, berdaya guna serta praktis. Keunggulan dari buku saku digital menurut ( $\mathrm{R}$ et al., 2019) yaitu selain ukurannya yang kecil tentunya dapat dibawa kemana-mana. Bisa disimpan di laptop, smartphone, PC dan perangkat lainnya yang mendukung dan dapat membaca buku digital tersebut. Dengan adanya buku saku digital diharapkan dapat membangkitkan semangat siswa dalam belajar.

\section{e. Pemrograman Dasar \\ Pemrograman dasar merupakan pemrograman} yang memberikan dasar logika, dimana sintak yang diberikan bersifat universal dan mengutamakan pembentukan cara berpikir seseorang mengenai bagaimana membuat program yang efektif dan efisien. Pada dasarnya, pemrograman pada tingkat yang lebih lanjut memiliki logika dan bentuk yang berbeda, bergantung pada programmernya. Dalam hal keberhasilan, efisiensi, dan kepraktisan interaksi dengan pengguna program dipengaruhi oleh algoritma dari programmernya. 


\subsection{Model Penelitian}

Jenis penelitian yang dilaksanakan adalah penelitian dan pengembangan Research and Development atau disingkat R \& D yaitu penelitian yang bertujuan untuk menghasilkan sebuah produk dan menguji keefektifan atau kelayakan dari produk tersebut (Sugiyono, 2018). Model pengembangan pada penelitian ini menggunakan model ADDIE. Model pengembangan pada penelitian ini menggunakan model ADDIE. Adapun tahapan model ADDIE yaitu analysis, design, development, implementation dan evaluation.

Bagan alur prosedur pengambangan buku saku digital berbasis android menggunakan model pengembangan ADDIE yang terdiri dari analysis (analisis), design (desain), development (pengembangan), implementation (implementasi), dan evaluation (evaluasi) yang ditunjukkan pada Gambar 2.2.

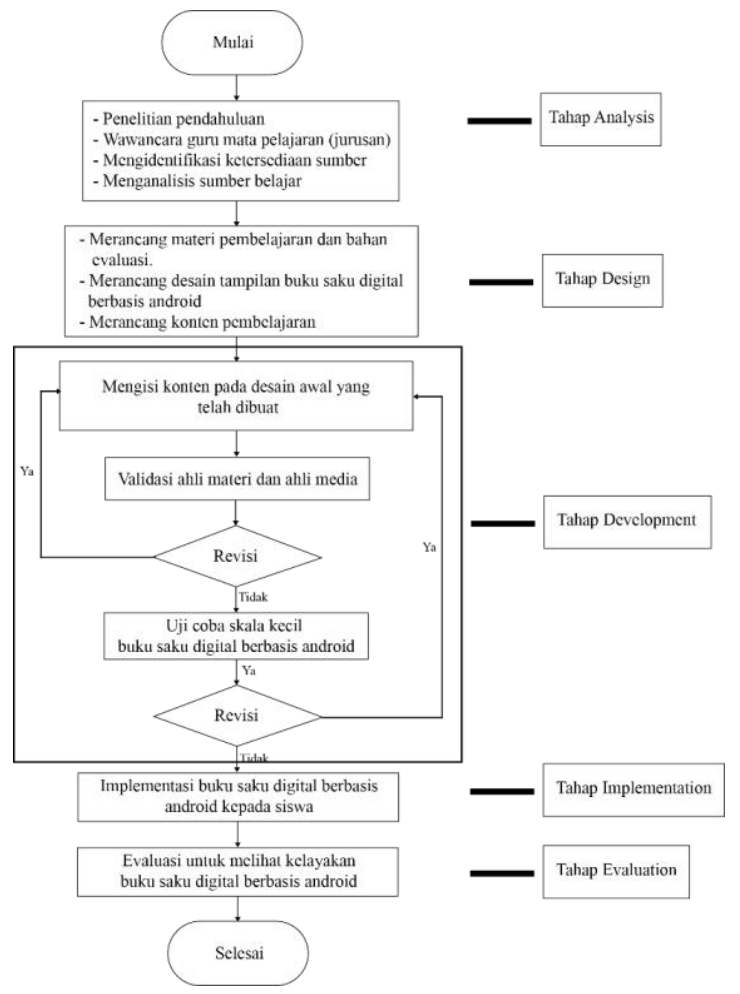

Gambar 1. Alur Pengembangan Buku Saku Digital Berbasis Android

\section{PEMBAHASAN}

Pengembangan buku saku digital berbasis android menggunakan model ADDIE yaitu analysis, design, development, implementation dan evaluation. Tahap pertama yaitu analysis, (1) peneliti melakukan analisis berdasarkan penelitian awal dengan melakukan review beberapa artikel untuk mengetahui apa yang akan diteliti serta, memperjelas masalah yang akan diteliti; (2) analisis kebutuhan dan identifikasi masalah dengan melakukan observasi kesekolah untuk mengumpulkan informasi dengan melakukan wawancara terhadap salah satu guru produktif di SMK Yapalis Krian. Berdasarkan observasi tersebut siswa mengalami kesulitan dalam memahami materi pelajaran yang telah disampaikan oleh guru. Jam belajar siswa pun terbatas dan siswa tidak dapat melakukan praktikum dilaborarotirum sehingga hasil belajar siswa mengalami penurunan, khususnya pada mata pelajaran pemrograman dasar. Seiring dengan perkembangan teknologi, penggunaan smartphone saat menjadi salah satu alternatif untuk melaksanakan proses pembelajaran jarak jauh sehingga siswa tetap dapat belajar kapanpun dan dimanapun.; (3) Analisis kompetensi berkaitan dengan Kompetensi Dasar (KD) yang akan dimuat dalam buku saku digital berbasis android. Pada tahap ini kompetensi minimal harus dicapai oleh siswa sesuai dengan indikator yang telah ditentukan; (4) Analisis karakteristik siswa untuk melihat sikap siswa terhadap mata pelajaran pemrograman dasar agar pengembangan buku saku digital sesuai dengan karakteristik siswa. Selanjutnya tahap design membuat rancangan storyboard kemudian didesain dengan menngunakan Adobe Illustrator serta merancang konten pembelajaran. Tahap ketiga yaitu development yang bertujuan menghasilkan produk berupa buku saku digital berasis android. Tahap pengembangan ini menggunakan software Adobe Animate CC dengan menggunakan action script 3.0 yang di gunakan untuk pembuatan aplikasi android dengan format landscape. Selain itu proses tahap pengembangan dilakukan validasi oleh ahli media, ahli materi dan respon siswa.

\subsection{Bentuk Buku Saku Digital Berbasis} Android

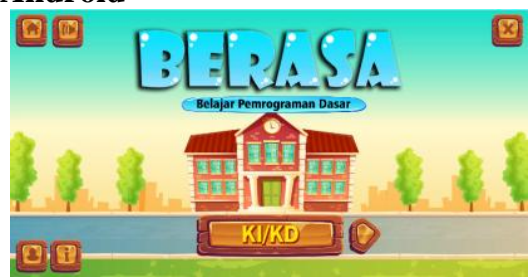

Gambar 2. Halaman Awal

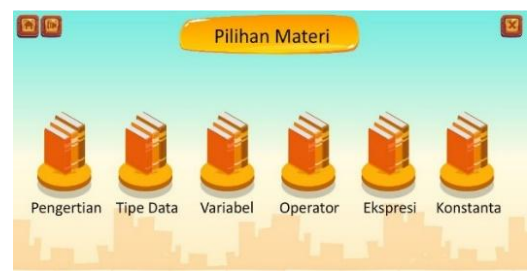

Gambar 3. Halaman Materi

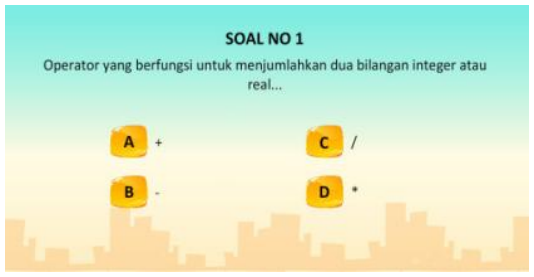

Gambar 4. Halaman Latihan. 


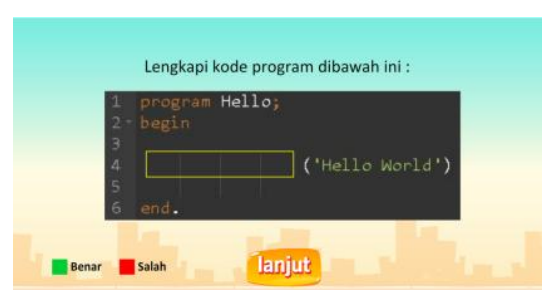

Gambar 5. Halaman Game.

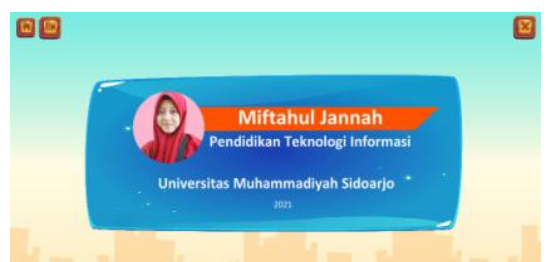

Gambar 6. Halaman Profil Pengembang.

\subsection{Kelayakan Buku Saku Digital}

Setelah media sudah dikembangkan maka selanjutnya yaitu dilakukan proses validasi, yaitu validasi ahli media dan ahli materi untuk mengetahui apakah media dan materi dalam buku saku digital tersebut sudah layak atau terdapat perbaikan. Validator ahli media yaitu Dosen Universitas Muhammadiyah Sidoarjo dan validator ahli materi yaitu Guru Mata Pelajaran Pemrograman Dasar SMK Yapalis Krian. Persentase yang diperoleh oleh ahli media dan ahli materi ditunjukkan pada Tabel 1.

Tabel 1. Hasil Penilaian Media

\begin{tabular}{llll}
\hline No. & Validator & Persentase & Keterangan \\
\hline 1. & Media & $85 \%$ & Sangat Layak \\
\hline 2. & Materi & $92 \%$ & Sangat Layak \\
\hline
\end{tabular}

Berdasarkan hasil validasi ahli media yaitu 85\% dengan kriteria Sangat Layak digunakan, hasil dari validasi ahli materi yaitu $92 \%$ dengan kriteria Sangat Layak digunakan.

Setelah dilakukannya validasi yaitu selanjutnya buku saku digital berbasis android dilakukan uji coba skala kecil kepada 5 siswa kelas XI yang telah mendapatkan materi pemrograman sebelumnya. Dari hasil uji coba tersebut akan mendapat hasil berupa respon siswa. Hasil uji coba skala kecil dapat ditunjukkan pada Tabel 2.

Tabel 2. Hasil Uji Coba.

\begin{tabular}{llll}
\hline No. & Nama siswa & Presentase & Keterangan \\
\hline 1. & MW & $80 \%$ & Layak \\
\hline 2 & NA & $70 \%$ & Layak \\
\hline 3 & AC & $80 \%$ & Layak \\
\hline 4 & AD & $98,3 \%$ & Sangat Layak \\
\hline 5 & RP & $91,6 \%$ & Sangat Layak \\
\hline Rata & Rata & $\mathbf{8 3 , 9 8 \%}$ & \\
\hline
\end{tabular}

Berdasarkan Tabel 4.3 diperoleh persentase rata rata sebesar 83,98 \% sehingga Buku Saku Digital dinyatakan sangat layak untuk digunakan.

\section{KESIMPULAN}

Berdasarkan hasil penelitian yang dilakukan dapat disimpulkan yaitu :

1. Buku saku digital yang dikembangkan berupa produk aplikasi android sebagai bahan pembelajaran pada mata pelajaran pemrograman dasar. Proses pengembangan buku saku digital berbasis android dengan mengunakan model pengembangan ADDIE dimulai dari tahap analysis, design, development, implementation dan evaluation. Produk akhir yang dihasilkan yaitu buku saku digital berupa aplikasi yang dapat dijalankan diperangkat mobile atau smartphone dengan sistem operasi android dengan manimum versi android 5.0.

2. Pengembangan buku saku digital berbasis android ini telah teruji kelayakannya yaitu telah divalidasi oleh ahli materi dan ahli media serta telah dilakukan uji coba skala kecil terhadap 5 siswa. Adapun hasil dari validasi ahli media yaitu $85 \%$ dengan kriteria Sangat Layak digunakan, hasil dari validasi ahli materi yaitu 92\% dengan kriteria Sangat Layak digunakan dan respon siswa mendapatkan rata - rata yaitu 83,98 \% dengan kategori sangat layak untuk digunakan.

\section{PUSTAKA}

Agustina, A. (2018). Upaya Menerapkan Kemampuan Guru Menerapkan Bahan Ajar di SMA Negeri 3 Ogan Komering Ulu. Jurnal Educative, 3(1), 21.

Anisah, A., \& Azizah, E. N. (2016). Pengaruh Penggunaan Buku Teks Pelajaran dan Internet sebagai Sumber Belajar Terhadap Hasil Belajar Siswa pada Pembelajaran IPS (Eksperimen Kuasi Pada Kelas VII di SMP Negeri 1 Palimanan Kabupaten Cirebon). Jurnal Logika, 18(3), 1-18. http://jurnal.unswagati.ac.id/index.php/logika/ article/viewFile/215/138

Aprelliyanto, Y. (2019). Pengembangan Bahan Ajar Ipa Berbasis Android Materi Gaya Dan Gerak Kelas Iv Sdn Kembangarum 02 Semarang. Universitas Negeri Semarang.

Billett, S. (2011). The Standing of Vocational Education. Societal Esteem and Implications for Its Enactment, 11(2), 10-14.

Edi, S., Suharno, S., \& Widiastuti, I. (2017). Pengembangan Standar Pelaksanaan Praktik Kerja Industri (Prakerin) Siswa Smk Program Keahlian Teknik Pemesinan Di Wilayah Surakarta. Jurnal Ilmiah Pendidikan Teknik Dan Kejuruan, $10(1), \quad 22$. https://doi.org/10.20961/jiptek.v10i1.14972

Faiqoh, A., Firmania, N., \& Wibawa, A. P. (2015). Pengembangan modul cetak dan visualisasi algoritma pemrograman dasar untuk smk kelas x. Seminar Nasional Teknologi Informasi Dan 
Multimedia, 6-8.

Hanif, M. (2018). Pengembangan Media Pembelajaran Buku Saku Digital untuk Kompetensi Dasar Teknik Memperoleh Modal Usaha Kelas X Pemasaran SMK. Jurnal Pendidikan Tata Niaga ( JPTN ), 06(ISSN : 2337-6708), 145-150.

Hernawan, A. H., Permasih, \& Dewi, L. (2017). Pembangan Bahan Ajar. 1489-1497. http://file.upi.edu/Direktori/FIP/JUR._KURIK ULUM_DAN_TEK._PENDIDIKAN/1946012 91981012PERMASIH/PENGEMBANGAN_BAHAN_ AJAR.pdf

Kemdikbud. (2014). Pemrograman Dasar.

Kusumam, A., Mukhidin, M., \& Hasan, B. (2016). Pengembangan Bahan Ajar Mata Pelajaran Dasar dan Pengukuran Listrik untuk Sekolah Menengah Kejuruan. Jurnal Pendidikan Teknologi Dan Kejuruan, 23(1), 28. https://doi.org/10.21831/jptk.v23i1.9352

Mastura, \& Santaria, R. (2020). Dampak Pandemi Covid-19 terhadap Proses Pengajaran bagi Guru dan Siswa Pendahuluan. Jurnal Studi Guru Dan Pembelajaran, 3(2), 289-295.

Nasional, D. P. (2008). Kamus Bahasa Indonesia. In Acta Universitatis Agriculturae et Silviculturae Mendelianae Brunensis (Pusat Baha).

Putri, Y. F. (2017). Pengembangan Aplikasi Buku Saku Berbasis Android Sebagai Media Pembelajaran Hukum Kesehatan di Akademi Farmasi Surabaya. It-Edu, 2(02).

R, N., Izzatin, M., \& Mucti, A. (2019). Desain pengembangan buku saku digital matematika smp berbasis android sebagai media pembelajaran dalam meningkatkan minat belajar siswa. Edukasia, 6, 4-17.

Rahmawati, G. (2016). Buku Teks Pelajaran Sebagai Sumber Belajar Siswa di Perpustakaan Sekolah di SMASN 3 Bandung. Edulib, 5(1), 102-113. https://doi.org/10.17509/edulib.v5i1.2307

Renesia. (2020). 10 Alasan Memilih Jurusan Multimedia. Https:/Www.Renesia.Com/10Alasan-Memilih-Jurusan-Multimedia/.

Sugiyono. (2018). Metode Penelitian Pendidikan Pendekatan Kuantitatif, Kualitatif dan $R \& D$. Alfabeta.

Suryaningsih, A. (2020). Peningkatan Motivasi Belajar Siswa Secara Online Pada Pelajaran Animasi 2D Melalui Strategi Komunikasi Persuasif. Ideguru: Jurnal Karya Ilmiah Guru, 5(1), 9-15. https://doi.org/10.51169/ideguru.v5i1.143 